\title{
INFLUENCE OF AIR MASS LONG-RANGE TRANSPORT ON OZONE CONCENTRATION AT PREILA SITE (LITHUANIA)
}

\author{
S. Byčenkienè and R. Girgždienė \\ Institute of Physics, Savanoriu 231, LT-02300 Vilnius, Lithuania \\ E-mail: bycenkiene@ar.fi.lt
}

Received 5 January 2006

\begin{abstract}
Ground-level ozone measurement data and air mass backward trajectories were used to determine the influence of the longrange transport on the ozone level. A cluster algorithm was implemented to analyse the backward trajectories of air masses arriving from North America to the Preila site located on the eastern coast of the Baltic Sea. The 10-day air mass backward trajectories were clustered and grouped according to season, travelled way, and height over the surface before arrival. Dominant air mass transport from North America was identified in the late autumn-winter (up to $69 \%$ of total events). The air masses from the "unpolluted" cluster in all seasons, except summertime, showed slightly higher ozone concentrations than those from the "polluted" cluster. The highest ozone concentration of $78 \pm 12 \mu \mathrm{g} \mathrm{m}^{-3}$ was found in air masses that travelled at the $>2 \mathrm{~km}$ height above the surface from the "unpolluted" cluster during a winter period. It was established that the transport of air masses from North America was mainly associated with cyclones $(65 \%)$. The change in the ozone level at the Preila site was up to $\pm 10 \mu \mathrm{g} \mathrm{m}^{-3}$ during the episodes when the transport of air masses from North America was detected.
\end{abstract}

Keywords: ozone, concentration, air mass transport backward trajectories, long-range scale, North America

PACS: 92.70.Cp, 92.60.hf, 92.60.Sz

\section{Introduction}

The tropospheric air quality over Europe has changed significantly since the beginning of industrialization [1-3]. The increase of ground-level ozone $\left(\mathrm{O}_{3}\right)$, as a major component of smog, is recognized as an urgent matter because of great concern about the public health in many parts of the world. For a long time it has been supposed to be a local, urban problem, but in recent years it has become evident that ozone is a regional pollutant, which can be transported across country borders. During the past decades, organized investigation campaigns, data analyses, and continuous improvement of air pollution modelling expanded our knowledge of the paths and scales of pollutant transport and transformation.

Air pollution involves the aerial transport of pollutants between the emission source and the sites of deposition as well as the chemical transformation of the pollutants in the atmosphere. The pollutants and trace gases are not only chemically removed by atmospheric processes but they also can be transformed into secondary pollutants. The ozone is an appropriate example of the secondary pollutant, because it can be formed by the reaction of nitrogen oxides and hydrocarbons in sunlight. The air pollution level is generally determined by weather conditions and atmospheric chemistry. Although we often have the information of the pollution situation, the reasons and pollutant sources are not sufficiently defined. It should be noted that in recent years several studies documenting the clear evidence for intercontinental transport of ozone, ozone precursors, and other chemical compounds have appeared. Measurements have shown that ozone pollution from North America is easily detectable even at the distance of $1500 \mathrm{~km}$ [4]. Similarly, measurements performed in the North Atlantic about $3000 \mathrm{~km}$ from the sources have revealed that pollutants from North America increase the ozone level in spring [5]. Therefore, the heavily polluted eastern coast of North America is a particularly powerful source of $\mathrm{O}_{3}$ and its precursors. Transport can have a major impact on the troposphere chemistry over the North Atlantic Ocean and Western European regions. It is evident that the average $\mathrm{O}_{3}$ level in Western Europe has doubled since preindustrial times and $\mathrm{O}_{3}$ levels increased throughout the lower troposphere over Europe during the last 50 years $[6,7]$. Although Europe itself is a powerful source of ozone, its increased levels in Europe may be partially attributable to long-range transport from North Amer- 
ica. Common trace gases include carbon monoxide (CO), ozone, nitrogen oxides $\left(\mathrm{NO}_{x}\right)$, sulphur dioxide $\left(\mathrm{SO}_{2}\right)$, and hydrocarbons. Ozone is regarded as a secondary pollutant as it is produced by photochemical activity in the presence of precursors. Pollutants have longer lifetimes in the upper troposphere, because there temperatures are lower and there is no surface deposition loss, i. e., favourable conditions for the long-range transport of pollutants are created [8].

There are indications that pollutants, even compounds with essentially short lifetimes, can be detected at large distances from their source. These facts initiated the quantitative estimation of the amount of anthropogenic ozone transported from North America. The cumulative study results have helped to reveal that ground-level ozone and its precursors can be transported over several thousand kilometers. Furthermore, depending on prevailing weather conditions, ozone can pass the borders in either direction so that two countries are at the same time the recipient and a provider of air pollutants.

The lifetime of the ozone precursor $\mathrm{NO}_{x}$ is relatively short (hours to days) but the produced ozone has a lifetime of days to months (in upper troposphere), and it may be transferred because typical transport times between continents are 5-10 days $[9,10]$. This enables the intercontinental transport of ozone and its precursors from North America and they can contribute to the pollution of the troposphere over Europe $[11,12]$. One of the key questions related to the intercontinental pollution transport is how much the ozone level over Europe is affected by ozone and its precursors from North America. Typical values of ozone in the remote Northern Hemisphere range from 20 to $50 \mathrm{ppb}$, depending on season and altitude [13]. North American anthropogenic emissions are estimated to contribute up to $10 \mathrm{ppb}$ to European ozone during the summer [14].

Frontal lifting of air in the North American boundary layer towards the Atlantic is the dominant export pathway of pollution [14-16]. The primary direction for transport of North American pollutants to the North Atlantic in the summertime is toward the northeast. However, the motion of the air masses in the warm sector ahead of advancing cold fronts has been identified as the most important process for the transfer of pollution from the urbanized eastern coast of United States to the North Atlantic [9]. This mechanism provides a means to rapidly and effectively transport large amounts of relatively short-lived pollutants over long distances.

In the recent 20 years trajectory analysis techniques are successfully used in the environmental studies of the long-range transport of pollutants, dust, or stratospheric ozone $[9,17,18]$. It is a useful method for studying the air pollution variations in the atmosphere and is helpful in identifying the origin and history of air masses coming to the site. Trajectories computed by the FLEXTRA model $[15,19]$ have been first used to establish the intercontinental transport of ozone [16] and Canadian forest fire emissions over Europe [12] as well as global air stream climatology [20].

The aim of this study is to apply the air mass trajectory filtration method and investigate the possible contribution of the air mass transport from North America to the ozone level at the Preila site.

\section{Methods}

In order to evaluate the contribution of the transport of air masses to the ozone concentration level, we have analysed the ozone data recorded at the Preila site in 1997. To determine possible transport pathways, the air mass backward trajectory method was applied. The relevant air masses were identified by using a filter function [21] applied to the calculated backward trajectories. In this paper, we focus on the study domain, which covers North America and European regions from $150^{\circ} \mathrm{W}$ to $80^{\circ} \mathrm{E}$ and from $30^{\circ} \mathrm{N}$ to $60^{\circ} \mathrm{N}$.

\subsection{Measurement site}

The Preila site $\left(55^{\circ} 22^{\prime} \mathrm{N}\right.$ and $21^{\circ} 02^{\prime} \mathrm{E}, 5 \mathrm{~m}$ above sea level) is located in the western part of Lithuania on the seashore of the Baltic Sea, on the Curonian Spit, far from the urban areas. There are no large sources of anthropogenic pollution of the atmosphere close to the monitoring site. One of the nearest industrial cities, Klaipeda, is at a distance of about $40 \mathrm{~km}$ to the north, and the other, Kaliningrad (Russia), is $90 \mathrm{~km}$ to the south from the site.

\subsection{Air mass backward trajectories}

Three-dimensional 10-day backward trajectories of air masses that reached Preila at $725 \mathrm{hPa}$ were calculated employing the trajectory FLEXTRA model used in this study $[22,23]$. The model employs numerical meteorological data from the European Centre for Medium Range Weather Forecasts (ECMWF) [24]. The computation started from the Preila site for identifying the air mass paths and the origin of air masses, which could have an effect on ozone concentrations at the Preila site. Each trajectory extends 10 days back in 


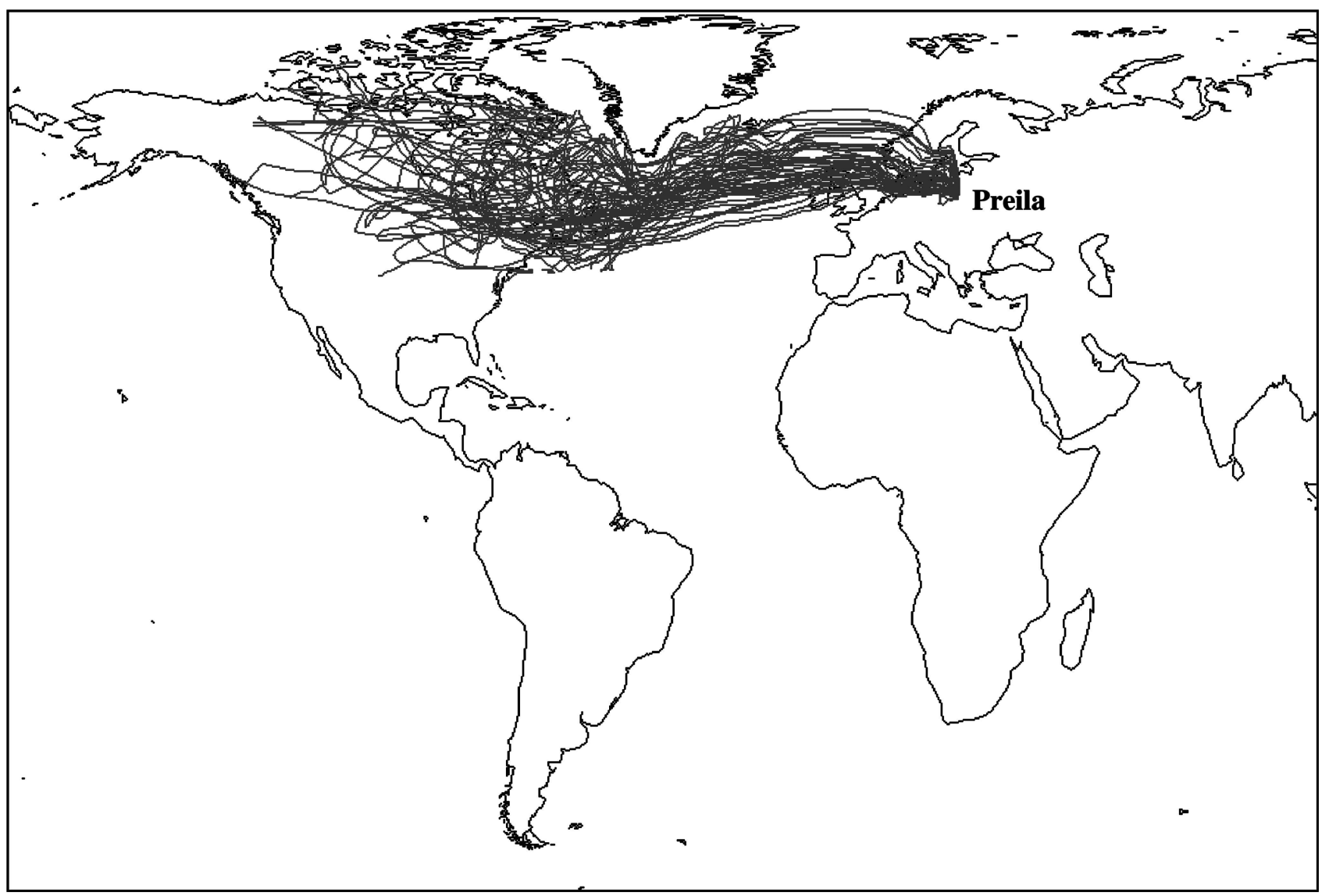

Fig. 1. Backward trajectories of air masses that reached Preila, showing an example of transport from the Northern America, 1997.

time with data output every three hours, resulting in a data set of 2491 trajectories.

\subsection{Filtering}

To classify the trajectories, cluster analysis was applied. According to this analysis, at first, the trajectories of the same origin (North America) (Fig. 1) were chosen and divided into two groups corresponding to two directions, south and north, before reaching the site. Thus, conditionally "unpolluted" air masses and "polluted" air masses, i.e., more influenced by European anthropogenic emissions, were separated out. All air masses travelled 5-6 days over the Atlantic Ocean. One day before arrival to the Preila site the average height of all trajectories was less than $1 \mathrm{~km}$ above the surface.

Moreover, the air mass trajectories were filtered according to the area they crossed. The filter should be built up of some triangular elements, forming a requested shape filter. Each trajectory was checked for having at least one point inside these filter elements and either filtered out or retained. The coordinates of applied filters are defined in Table 1.
Table 1. The coordinates of applied northern and southern filters (see Fig. 2).

\begin{tabular}{ccc}
\hline & Latitude, N & Longitude, E \\
\hline Northern filter & & \\
A & $67^{\circ} 00^{\prime}$ & $-1^{\circ} 00^{\prime}$ \\
B & $54^{\circ} 00^{\prime}$ & $-1^{\circ} 00^{\prime}$ \\
C & $67^{\circ} 00^{\prime}$ & $21^{\circ} 00^{\prime}$ \\
E & $54^{\circ} 00^{\prime}$ & $21^{\circ} 00^{\prime}$ \\
\hline Southern filter & & \\
A' & $53^{\circ} 00^{\prime}$ & $-7^{\circ} 00^{\prime}$ \\
B' & $37^{\circ} 00^{\prime}$ & $-7^{\circ} 00^{\prime}$ \\
C' & $53^{\circ} 00^{\prime}$ & $18^{\circ} 00^{\prime}$ \\
E' & $37^{\circ} 00^{\prime}$ & $18^{\circ} 00^{\prime}$ \\
\hline
\end{tabular}

The filtering process for the "northern filter", presented as triangles $\mathrm{ABC}$ and $\mathrm{BCE}$, was performed by the method explained below (see Fig. 2).

Trajectories are described by a number of points $(P$, $\left.P^{\prime}, P^{\prime \prime}\right)$. Point $D$ is known to lie outside of all filter triangles. By the method described in the paper [25] the points $P, P^{\prime}, P^{\prime \prime}$ must be checked for being inside the triangle, and intersection points $S, S^{\prime}, S^{\prime \prime}$ of line $\overline{D P}$ with all triangle lines $\overline{A B}, \overline{A C}$, and $\overline{B C}$ are calculated. Point $P$ is inside the triangle if one $S$ is exactly part 


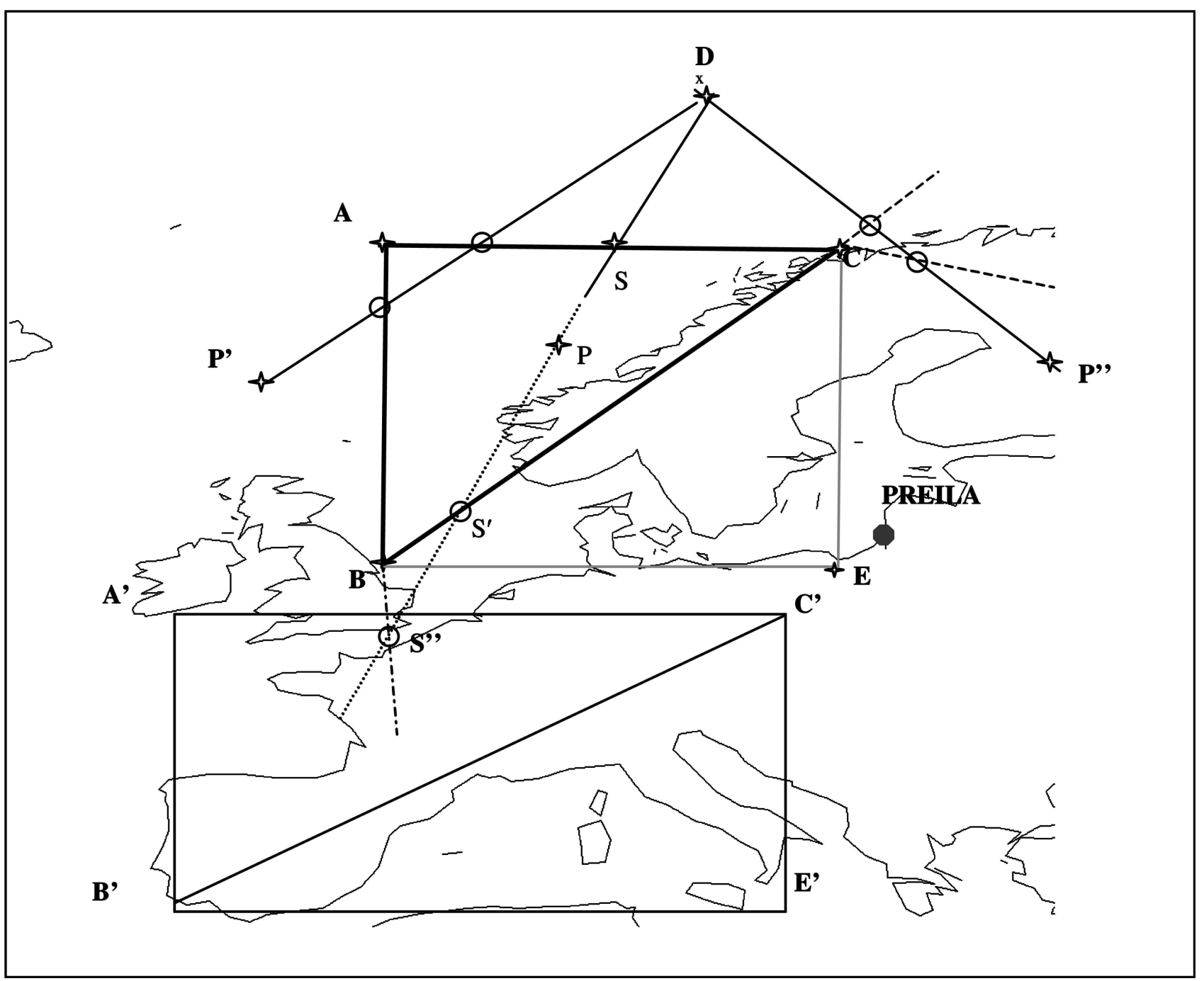

Fig. 2. The coordinates and position of the "south filter" and "north filter".

of the triangle side and part of $\overline{P D}$ at the same time. The corner points of the triangle are not accounted for as this could produce uncertainties in applying algorithms. In mathematical terms, the algorithm can be expressed as follows.

With $S=\overline{P D} \cap \overline{A B}, S^{\prime}=\overline{P D} \cap \overline{A C}, S^{\prime \prime}=\overline{P D} \cap$ $\overline{B C}$ and the prerequisite that $D$ is not inside $\triangle A B C$ the filter creation becomes $P$ inside $\triangle A B C \Rightarrow$

$$
\begin{aligned}
& \left(S \neq\{\} \wedge S^{\prime}=\{\} \wedge S^{\prime \prime}=\{\}\right) \vee \\
& \left(S=\{\} \wedge S^{\prime} \neq\{\} \wedge S^{\prime \prime}=\{\}\right) \vee \\
& \left(S=\{\} \wedge S^{\prime} \neq\{\} \wedge S^{\prime \prime} \neq\{\}\right) .
\end{aligned}
$$

First, the intersection points are calculated using a standard affine geometry. Then $S, S^{\prime}, S^{\prime \prime}$ must be checked for being between the start and end points of $\overline{P D}$ and the respective triangle sides.
Using the vector form, $\overline{P D}$ can be expressed as

$$
G_{\overline{P D}}: \vec{s}=\vec{p}+(\vec{d}-\vec{p}) t_{s}
$$

where $\vec{p}, \vec{s}$ are the point vectors of $P$ and $S$, respectively. Thus, a point $\vec{s} \in \overline{P D}$ is defined by its corresponding scalar $\mathrm{t}_{s} . \vec{s}$ is between the start and end points of a line, if $0 \leq t_{s} \leq 1$.

At first, the $t$-values of $S, S^{\prime}, S^{\prime \prime}$ are calculated for the segment $\overline{P D}$ and all triangle sides, then the criterion in Eq. (1) is applied, identifying the points being inside or outside the trajectory filter. During the filtering process, all points of a trajectory are checked for fulfilling Eq. (1). At least one point of a trajectory must fall into one of the filter elements. This is a so-called filter criterion. Based on the filtering mode, trajectories fulfilling the filter criterion can either be retained or rejected.

The same filtering steps were applied for the "southern filter" A'B'C'E'. 


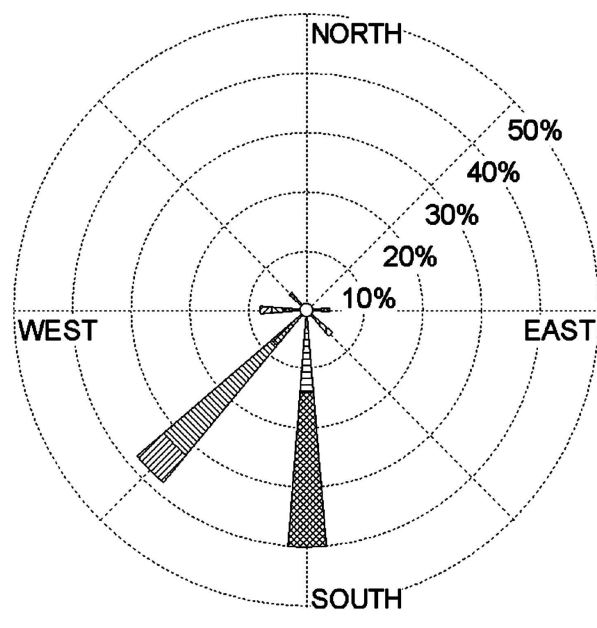

a) anticyclones

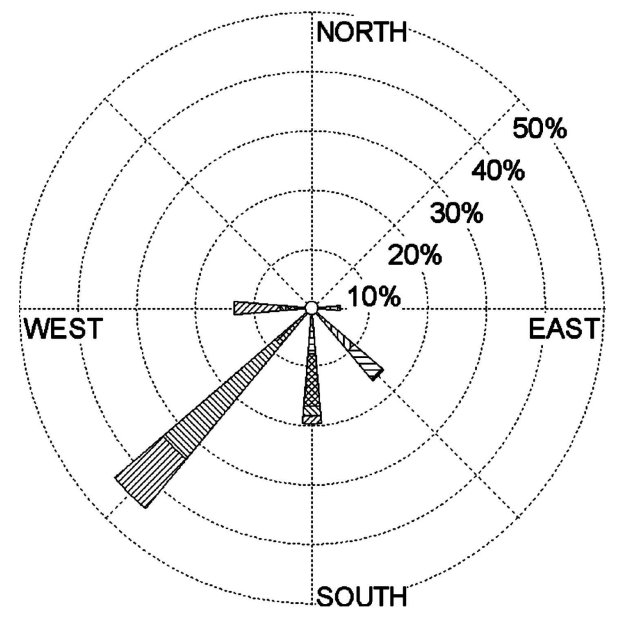

b) cyclones

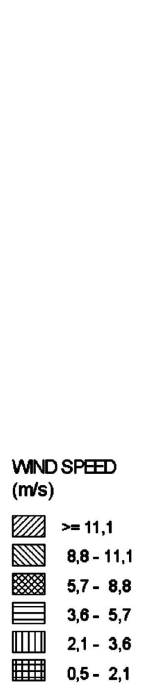

Calms: $0,00 \%$

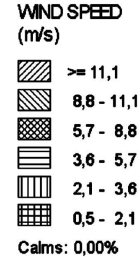

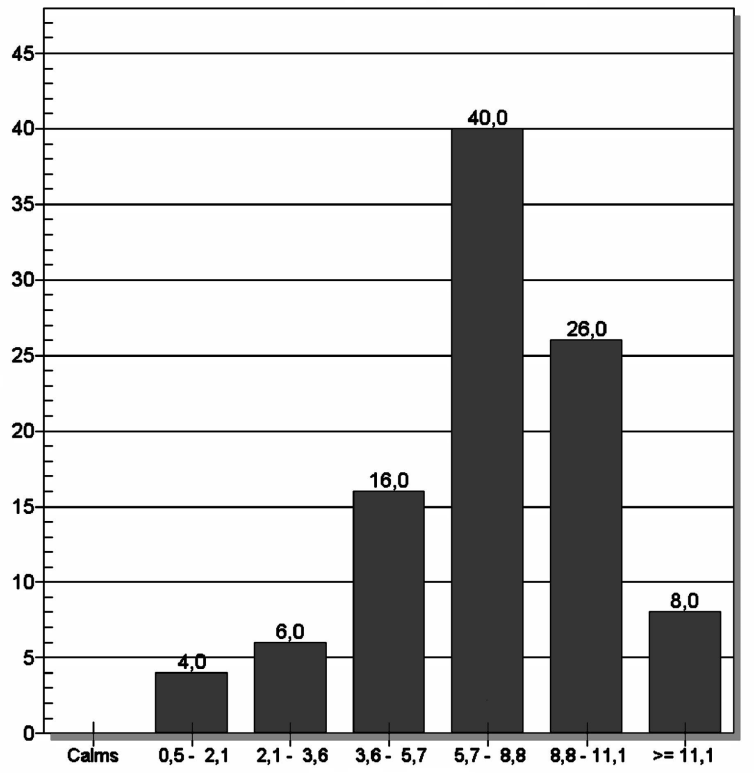

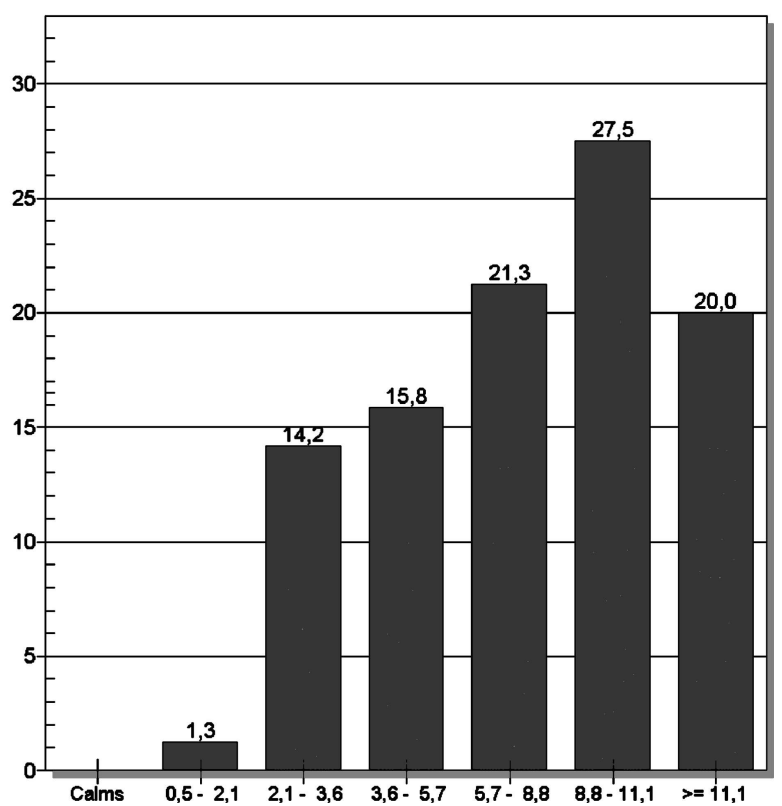

Fig. 3. Distribution of wind speed and direction in Preila, 1997.

\section{Results}

\subsection{Meteorological situation in 1997}

Weather conditions play a major role in short-term variations of air pollutants and long-term air quality trends. The synoptical situations were analysed referring to the data provided in meteorological bulletins of the Lithuanian Hydrometeorological Service. The weather during the study period was governed by cyclones, especially their southern and westward sides. Anticyclones were observed rarely, while the cyclones were dominant during June. The westward and southern parts of cyclone were characteristic in July.

The arrival of the air masses from North America was always associated with the cyclone $(65 \%$ of total events), or with well-defined low-pressure systems. The ozone concentration level depends on the local meteorology such as wind speed and direction, therefore, the wind data analysis during cyclone and anticyclone periods was performed. Figure 3 shows the frequency of the wind direction at each of the 8 major compass points (north, northeast, east, etc.) and six wind speed classes. The percentage frequency of calm wind and the scheme used for wind speed categories are depicted 
next to each wind rose plot. The range of directions between southeast and west was observed in the majority of cases. The wind roses in Fig. 3 illustrate the frequency of wind speed and direction during the year and provide evidence of the predominant S-SW direction.

It should be noted that $5.7-8.8 \mathrm{~m} \mathrm{~s}^{-1}$ winds prevailed during anticyclones (40\%), while the 8.8$11.1 \mathrm{~m} \mathrm{~s}^{-1}$ wind speed prevailed during cyclones. The wind speed $>11 \mathrm{~m} \mathrm{~s}^{-1}$ was observed in Preila more frequently during cyclones ( $20 \%$ of total events) than during anticyclones $(8 \%)$. The frequency distribution of winds at the Preila station during cyclone shows southwest flow but not so obviously as during anticyclone. A high frequency of winds during anticyclone was still from the southwest, but south winds were often observed as well. The potential local pollution sources located in the southwest and south near the station had no effect on the ozone level [26].

\subsection{Ozone}

The analysis of the ozone concentration monthly variations in all the air masses transported from North America to the Preila region was performed (Fig. 4). A different occurrence of such air masses during separate months was revealed. $69 \%$ of trajectories characterized the occurrence of the air masses transport during the cold season: in October (11\% of the total situations), December (11\%), February (31\%), and March (11\%). Just up to $31 \%$ of total events were observed during the warm season (April-September), confirming that the cold season was favourable for the air mass travel from North America to the site. It should be noted that no episode was observed during August.

The averages of ozone concentration during transatlantic transport events and during the remaining time were evaluated for separate months. The average ozone concentrations during transatlantic transport events were lower in January, March, June, July, October, and November; the values were very similar in Febru-

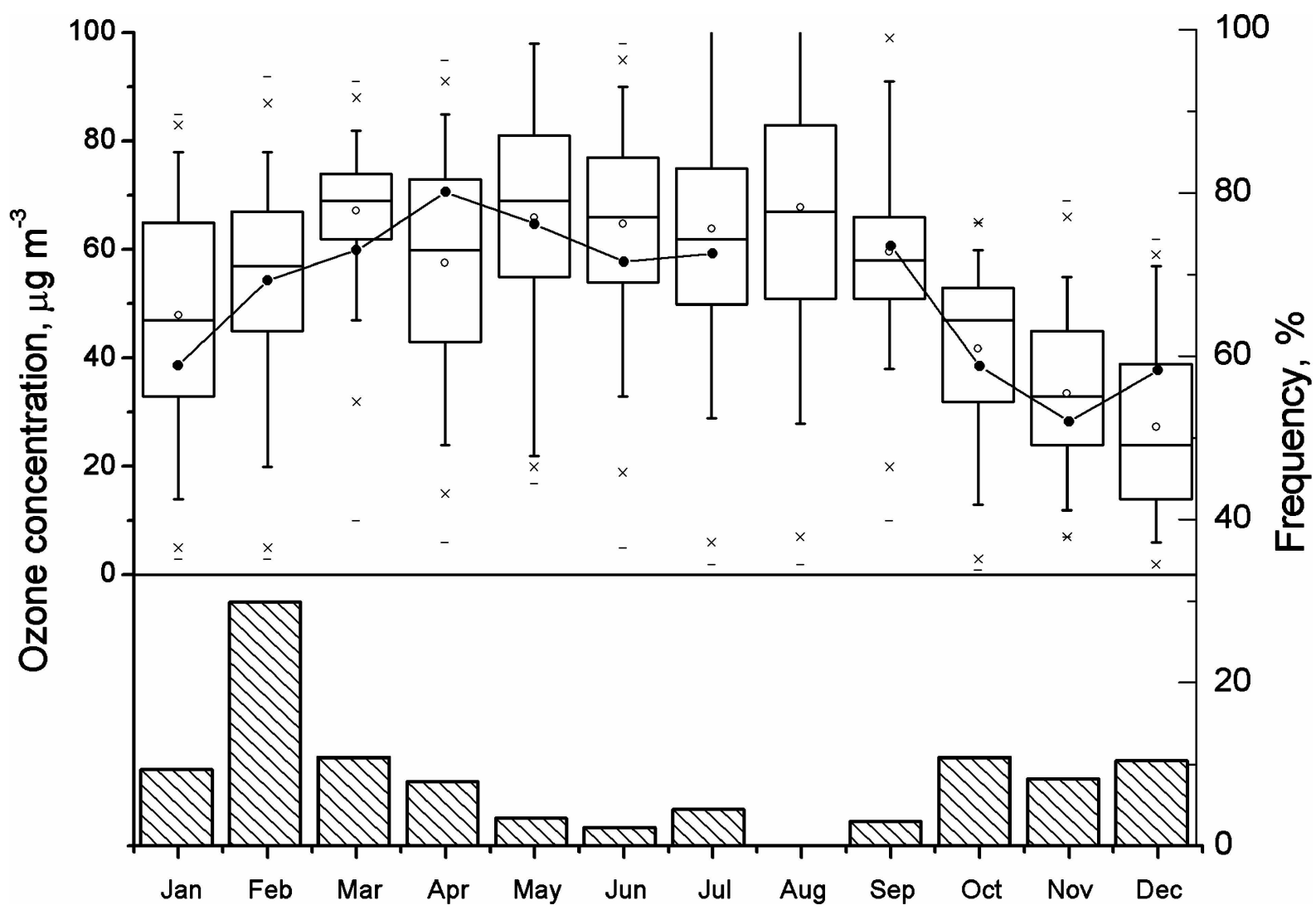

Fig. 4. Ozone concentration (box plots) variations and air mass transatlantic transport frequency (column) in 1997. The connected solid circles represent the average ozone concentration during transatlantic transport events. The horizontal lines in the box denote the 25th, 50th, and 75th percentile values. The error bars denote the 5th and 95th percentile values. The star below the 5th percentile error bar denotes the minimum value and the star above the 95th percentile error bar denotes the maximum value. The cycle symbol in the box denotes the monthly average of the ozone concentration without data during transatlantic transport events. The right scale indicates the frequency distribution of air mass backward trajectories. 
ary, May, and September. Only during April and December the average ozone concentration during transatlantic transport events exceeded that during the rest of the time. The ozone monthly average during transatlantic transport days shows a maximum of $71 \mu \mathrm{g} \mathrm{m}^{-3}$ in April and a minimum of $28 \mu \mathrm{g} \mathrm{m}^{-3}$ in November, while the peaks of $68 \mu \mathrm{g} \mathrm{m}^{-3}$ in August and of $67 \mu \mathrm{g} \mathrm{m}^{-3}$ in March, excluding data of transatlantic transport days, were observed. The obtained results showed that the differences in average ozone concentration during transatlantic transport events and during the rest of the time can be obvious, i.e., up to $\pm 10 \mu \mathrm{g} \mathrm{m}^{-3}$.

The ozone level in the air masses depends on pollution of the crossed region before reaching the site and on their moving height over the surface. Therefore, detailed analysis was made by grouping trajectories according to the areas, seasons, and height before arrival. The air mass backward trajectories were grouped into six clusters during the examined period. Figure 5 shows the variations in the average ozone concentration in Preila in these six clusters.

The first cluster ("south filter") is characterized by long-range transport with possible influences of South European industry. 449 trajectories (15\%) passed predominantly high emission industrial areas: France, Germany, Belgium, and Austria. The second cluster ("north filter") characterizes the long-range transport over North Europe. 641 trajectories (22\%) of air masses attributed to this cluster started from the Atlantic Ocean, passed Iceland, Norway, Sweden, and Finland and then reached the northern part of Europe. The average distance of the trajectory path, i. e., estimated trajectory origin / arrival point distance, through the "north filter" was $11465 \mathrm{~km}$; meanwhile their path length (summarized point-to-point length) was on average $13310 \mathrm{~km}$. A shorter distance and length on average of $10580 \mathrm{~km}$ and of $12030 \mathrm{~km}$, respectively, characterize the air mass transport through the "south filter". The length specifies the time of air masses residence over the crossed area between two points, i. e., if the air mass moves at a slower speed, its moving time as well as the trajectory length will increase, although the distance will remain the same. Not only the length but also the altitude of air mass transport varied greatly above the surface. Some air mass trajectories during the days of the transatlantic transport were rapidly uplifted to $2 \mathrm{~km}$. Thus, the third-sixth clusters ("north filter $>2 \mathrm{~km}$ ", "north filter $<2 \mathrm{~km}$ ", "south filter $>2 \mathrm{~km}$ " and "south filter $<2 \mathrm{~km}$ ") involve trajectories filtered by height in above-mentioned filters.

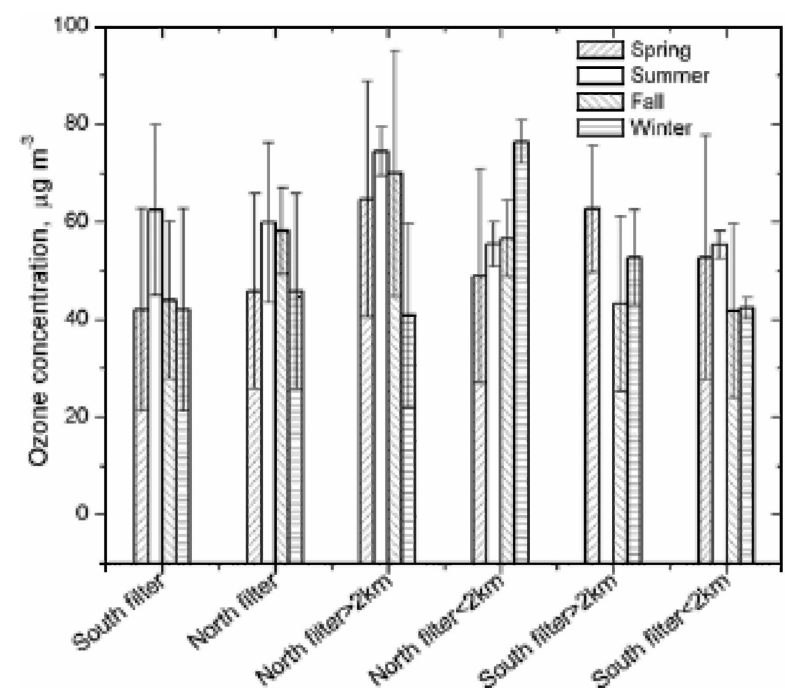

Fig. 5. The ozone concentration variations in different clusters.

The annual $\mathrm{O}_{3}$ concentration of $48 \pm 10 \mu \mathrm{g} \mathrm{m}^{-3}$ was obtained for the "south filter" and $52 \pm 8 \mu \mathrm{g} \mathrm{m}^{-3}$ for the "north filter". Comparing the ozone average values of filters (Fig. 5), some differences were evident. During spring ( $42 \pm 20 \mu \mathrm{g} \mathrm{m}^{-3}$ ), fall $\left(43 \pm 16 \mu \mathrm{g} \mathrm{m}^{-3}\right)$, and winter $\left(43 \pm 20 \mu \mathrm{g} \mathrm{m}^{-3}\right)$ the ozone concentrations for the "south filter" were recorded to be lower than for the "north filter" $\left(46 \pm 20,58 \pm 8\right.$, and $46 \pm 20 \mu \mathrm{g} \mathrm{m}^{-3}$, respectively). During summer slightly higher $\mathrm{O}_{3}$ concentrations were recorded in polluted air, i.e., the ozone concentration from the "north filter" cluster was $60 \pm 16 \mu \mathrm{g} \mathrm{m}^{-3}$ and from the "south filter" cluster $-62 \pm 17 \mu \mathrm{g} \mathrm{m}^{-3}$. In order to select more detailed information an additional restrictive criterion was applied. $\mathrm{O}_{3}$ values associated with the height of air masses transport (above/below $2 \mathrm{~km}$ ) were analysed. For these conditions, the highest $\mathrm{O}_{3}$ concentration of $78 \pm 12 \mu \mathrm{g} \mathrm{m}^{-3}$ was related to the "north filter $<2 \mathrm{~km}$ " during winter. After adjustment of these criteria, concentrations increased up to $65 \pm 8,74 \pm 9$, and $69 \pm 17 \mu \mathrm{g} \mathrm{m}^{-3}$ during spring, summer, and fall, respectively.

\section{Conclusions}

The air mass trajectory filtration method was applied to evaluate the intercontinental transport influence on the ozone concentration level. The analysis of the ozone concentration changes during the events of the air masses long-range transport to the Preila station region during 1997 was made. The analysis involved a total number of 1090 trajectories chosen according to the defined filters. $69 \%$ of these trajectories characterized the occurrence of the air masses 
transport during the cold season: in October (11\% of the total situations), December (11\%), February (31\%), and March (11\%) and just up to $31 \%$ during the warm season (April-September), confirming that the cold season was found to be favourable for the air mass travel from North America to the site.

Annual average of concentration of $48 \pm 10 \mu \mathrm{g} \mathrm{m}^{-3}$ was obtained for the "south filter" cluster and a slightly higher one, of $52 \pm 8 \mu \mathrm{g} \mathrm{m}^{-3}$, for the "north filter" cluster. Furthermore, comparing the ozone seasonal average concentration within the clusters some differences were obvious. The average ozone concentrations for the "south filter" during fall ( $\left.43 \pm 16 \mu \mathrm{g} \mathrm{m}^{-3}\right)$, winter $\left(43 \pm 20 \mu \mathrm{g} \mathrm{m}^{-3}\right)$, and spring $\left(42 \pm 20 \mu \mathrm{g} \mathrm{m}^{-3}\right)$ were recorded to be lower than for the "north filter" cluster $\left(58 \pm 8,46 \pm 20\right.$, and $46 \pm 20 \mu \mathrm{g} \mathrm{m}^{-3}$, respectively). Slightly higher ozone average concentration of $60 \pm 16 \mu \mathrm{g} \mathrm{m}^{-3}$ was estimated in the "north filter" cluster during the summer, whereas it was $62 \pm 17 \mu \mathrm{g} \mathrm{m}^{-3}$ in the "south filter" cluster. Besides, high concentrations of ozone were found with respect to the "north filter $>2 \mathrm{~km}$ " cluster during spring, summer, and fall. The long-range transport (up to $2 \mathrm{~km}$ and higher above the surface) from North America through the northern area of Europe could affect the ozone level at the Preila site. Ozone transatlantic transportation episodes are shown to be systematically $(65 \%)$ associated with low-pressure systems.

The carried out investigations have shown that during the episodes, when the transport of air masses from North America can be detected, the change in the ozone level at the Preila site was up to $\pm 10 \mu \mathrm{g} \mathrm{m}^{-3}$.

The calculations of the transatlantic transport influence were based on the assumption that ozone and its precursors in the air masses originate from North America, however the contributions from other sources are possible as well. Due to the relatively low occurrence of air mass transport from North America during separate months, the calculation of the change in ozone concentration can be approximate. The estimation will be revised after fulfilling the analogous analysis during a longer period.

\section{Acknowledgements}

The authors gratefully acknowledge A. Stohl for providing the FLEXTRA trajectories. The research described in this paper was partially supported by the Lithuanian State Science and Studies Foundation and the FP6 Network of Excellence ACCENT.

\section{References}

[1] J. Staehelin, J. Thudium, R. Buehlfr, and A. VolzThomas, Trends in surface ozone concentrations at Arosa (Switzerland), Atmos. Environ. 28, 75-87 (1994).

[2] S.J. Olmans, A.S. Lefohn, H.E. Scheel, J.M. Harris, H. Levy II, I.E. Galbally, E.-G. Brunke, C.P. Meyer, J.A. Lathrop, B.J. Johnson, D.S. Shadwick, E. Cuevas, F.J. Schmidlin, D.W. Tarasick, H. Claude, J.B. Kerr, O. Uchino, and V. Mohnen, Trends of ozone in the troposphere, Geophys. Res. Lett. 25, 139-142 (1998).

[3] J.A. Logan, I.A. Megretskaia, A.J. Miller et al., Trends in the vertical distribution of ozone: A comparison of two analyses of ozonesonde data, J. Geophys. Res. 104, 26,373-26,399 (1999).

[4] D.D. Parrish, J.S. Holloway, M. Trainer, P.C. Murphy, G.L. Forbes, and F.C. Fehsenfeld, Export of North American ozone pollution to the North Atlantic Ocean, Science 259, 1436-1439 (1993).

[5] D.D. Parrish, M. Trainer, J.S. Holloway, J.E. Yee, M.S. Warshawsky, F.C. Fehsenfeld, G.L. Forbes, and J.L. Moody, Relationships between ozone and carbon monoxide at surface sites in the North Atlantic region, J. Geophys. Res. 103, 13,357-13,376 (1998).

[6] S. Sandroni, D. Anfossi, and S. Viarenzo, Surface ozone levels at the end of nineteenth century in South America, J. Geophys. Res. 97, 2535-2539 (1992).

[7] A. Marenco, H. Gouget, P. Nedelec, and J.P. Pages, Evidence of a long-term increase in tropospheric ozone from Pic du Midi data series, Consequences: Positive radiative forcing, J. Geophys. Res. 99, 16,617-16,632 (1994).

[8] E.A. Donnell, D.J. Fish, E.M. Dicks, and A.J. Thorpe, Mechanisms for pollutant transport between the boundary layer and free troposphere, J. Geophys. Res. 106, 7847-7856 (2001).

[9] J.T. Merrill and J.L. Moody, Synoptic meteorology and transport during the North Atlantic Regional Experiment (NARE) intensive: Overview, J. Geophys. Res. 101, 28,903-28,921 (1996).

[10] C.M. Benkovitz, T. Scholtz, J. Pacyna, L. Tarrasn, J. Dignon, E. Voldner, P.A. Spiro, J.A. Logan, and T.E. Graedel, Global inventories of anthropogenic emissions of $\mathrm{SO}_{2}$ and $\mathrm{NO}_{x}$, J. Geophys. Res. 101, 29,239-29,253 (1996).

[11] O. Wild, K.S. Law, D.S. McKenna, B.J. Bandy, S.A. Penkett, and J.A. Pyle, Photochemical trajectory modeling studies of the North Atlantic region during August 1993, J. Geophys. Res. 101, 29,269-29,288 (1996).

[12] C. Forster, U. Wandinger, G. Wotawa, P. James, I. Mattis, D. Althausen, P. Simmonds, S. O’Doherty, S. Jennings, C. Kleefeld, J. Schnieder, T. Trickl, S. Kreipl, H. Jager, and A. Stohl, Transport of Canadian forest fire emissions to Europe, J. Geophys. Res. 106, 22,887-22,906 (2001). 
[13] S.J. Oltmans and H. Levy II, Surface ozone measurements from a global network, Atmos. Environ. 28, 924 (1994).

[14] Q. Li, D.J. Jacob, I. Bey, P.I. Palmer, B.N. Duncan, B.D. Fold, R.V. Martin, A.M. Fiore, R.M. Yantosca, D.D. Parrish, P.G. Simmonds, and S. Oltmans, Transatlantic transport of pollution and its effects on surface ozone in Europe and North America, J. Geophys. Res. 107, 4166, doi:10.1029/2001JD001422 (2002).

[15] A. Stohl, The FLEXTRA Trajectory Model Version 3.0.User Guide, http://www.forst.tu-muenchen.de/ EXT/LST/METEO/stohl/flextra/flextra3.html .

[16] A. Stohl and T. Trickl, A textbook example of longrange transport: Simultaneous observation of ozone maxima of stratospheric and North American origin in the free troposphere over Europe, J. Geophys. Res. 104, 30,445-30,462 (1999).

[17] A.I. Prados, R.R. Dickerson, B.G. Doddridge, P.A. Milne, J.L. Moody, and J.T. Merrill, Transport of ozone and pollutants from North America to the North Atlantic Ocean during the 1996 Atmosphere/Ocean Chemistry Experiment (AEROCE) intensive, J. Geophys. Res. 104, 26,219-26,233 (1999).

[18] P. James, A. Stohl, C. Forster, S. Eckhardt, P. Seibert, and A. Frank, A 15-year climatology of stratosphere-troposphere exchange with a Lagrangian particle dispersion model 2. Mean climate and seasonal variability, J. Geophys. Res. 108, 8522, doi:10.1029/2002JD002639 (2003).

[19] A. Stohl, Computation, accuracy and applications of trajectories - a review and bibliography, Atmos. Environ. 32, 947-966 (1998).

[20] A. Stohl, A one-year Lagrangian "climatology" of airstreams in the Northern Hemisphere troposphere and lowermost stratosphere, J. Geophys. Res. 106, 7263-7279 (2001).

[21] H. Sodemann, A new software tool for air mass trajectory visualization and exploration, in: Proceedings from the EUROTRAC-2 Symposium, eds. P.M. Midgley and M. Reuther (2002).

[22] A. Stohl and P. Seibert, Accuracy of trajectories as determined from the conservation of meteorological tracers, Q. J. Roy. Met. Soc. 124, 1465-1484 (1998).

[23] The FLEXTRA and FLEXPART homepage by Andreas Stohl and others, http://zardoz.nilu.no/ andreas/ flextra+flexpart.html .

[24] User Guide to ECMWF Products 2.1, Meteorological Bulletin M3.2 (ECMWF, 1995).

[25] Trajectory filtering, in: PLOTRA A software For Air Mass Trajectory Data Exploration and Visualization (User manual by H. Sodemann), pp. 25-27.

[26] R. Girgzdiene and A. Girgzdys, The influence of wind parameters on the ozone concentration variation on the Baltic Sea coast, Environmental Chem. Phys. 23(3-4), 112-117 (2001).

\title{
ORO MASIŲ TOLIMŲJŲ PERNAŠŲ ITAKA OZONO KONCENTRACIJAI PREILOS STOTYJE
}

\author{
S. Byčenkienè, R. Girgždienè \\ Fizikos institutas, Vilnius, Lietuva
}

\section{Santrauka}

Remiantis Preilos stotyje išmatuotų pažemio ozono koncentracijų ir oro masių atgaliniu trajektoriju analize, ịvertintos vidutinès ozono koncentracijos oro masèse, atejusiose iš Šiaurès Amerikos. Analizuotos 1997 metų oro masių 10 dienų judejimo atgalinès trajektorijos suskirstytos i dvi dideles grupes pagal teritorijas (,užterštas“ ir „,neužterštas“ sektorius), kurias kirto oro masès. Vèliau kiekviena grupè surūšiuota ị pogrupius pagal oro masių slinkimo kryptį, aukštị ir sezonus. Didžiausias oro masių, atėjusių iš Šiaurès Amerikos ị Preilą, pasikartojimas buvo vèlyvą rudenįžiemą, tuo tarpu rugpjūčio mẻnesi tokiu atvejų nebuvo užregistruota. Ivertinti ozono koncentraciju pokyčiai atskirais sezonais skirtingiems oro masių trajektoriju pogrupiams. Nustatyta, kad visais metu laikais, išskyrus vasaros laikotarpi, ozono koncentraciju vidurkiai (rudeni $58 \pm 8$, žiemą $46 \pm 20$ ir pavasarị $46 \pm 20 \mu \mathrm{g} \mathrm{m}^{-3}$ ) grupeje iš ,neužteršto“ sektoriaus buvo didesni negu iš „,užteršto“ sektoriaus ( $\left.43 \pm 16,43 \pm 20,42 \pm 20 \mu \mathrm{g} \mathrm{m}^{-3}\right)$. Didžiausiomis vidutinèmis ozono koncentracijomis $\left(78 \pm 12 \mu \mathrm{g} \mathrm{m}^{-3}\right)$ pasižymèjo oro masès iš „neužteršto“ sektoriaus, judejusios žiemą virš 2 km aukštyje prieš nusileidžiant ị Preilą. Oro masių atèjimo nuo Šiaurès Amerikos laikotarpiais virš Lietuvos vyravo ciklonai arba silpnai išreikšti žemo slègio laukai (65\% visų atveju). Tarpkontinentinès tolimosios pernašos galèjo turèti įtakos ozono koncentracijos lygiui Preilos stotyje atskirais 1997 metų atvejais, t. y., galèjo padidinti arba sumažinti koncentraciją iki $10 \mu \mathrm{g} \mathrm{m}^{-3}$. 